poddana została niepetnej, fragmentarycznej analizie. Poza kilkoma sugestiami nie badano Wrońskiego z punktu widzenia ówczesnych potrzeb edukacyjnych, dominował $w$ prezentacji Filozofii Pedagogii typ raczej opisowy niż krytyczny; układ częściej chronologiczny niż problemowy, stąd i sam Wroński pozostał samotną wyspa bez szerszych odniesien. Zaskakującym paradoksem jest fakt, że wysokie oceny umysłow ości Wrońskiego szły w parze z milczeniem o nim w ówczesnej (a tym bardziej we współczesnej) historii wychowania. Będąc rzeczywiście genialnym prekursorem wielu poczynań następnego stulecia nie powinien zostać zapomniany. W czasopiśmiennictwie, które najszybciej reagowało na nowe trendy, brak, poza zbyt dowolną interpretacją Walsera, głębszych prób operacjonalizacji filozofii wychowania Wrońskiego. Wydaje się również, i to dotyczy także prezentowanych rozpraw, że nie doceniano oryginalności i samodzielności tego mesjanisty. Jego system filozofii uniwersalnej nie da się sprowadzić (zredukować) do jakiejś źródłowej doktryny pedagogicznej na zachodzie. Był on samotnym żeglarzem zarówno w życiu codziennym, jak i na polu nauki. W nauce - jak pisal Hessen - pytania sq te same, zmieniają się tylko odpowiedzi. Wroński sięgnął do jądra problematyki pedagogicznej i dał swoją odpowiedź na pytanie o stałość i zmienność w naukach pedagogicznych - pytanie, które nadal pozostaje otwarte.

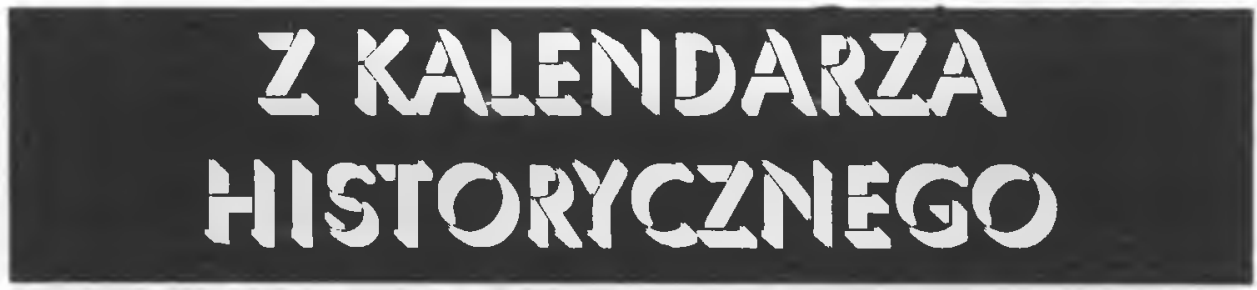

Kazimierz Denek

Poznań

\title{
Trzy ćwierćwiecza krajoznawstwa i turystyki w polskiej szkole
}

Nic tak dobrze nie charaktaryzuje natury zjawiska społecznego, jak poznanie przyczyn jego powstania, ewolucji, tradycji. Zatem przyjrzyjmy się historii krajoznawstwa i turystyki w naszym kraju ze szczególnym uwzględnieniem jednego $z$ jej nurtów, jakim jest szkolny ruch krajoznawczo-turystyczny. Nie sposób bowiem mówić o współczesnym kształcie tego ruchu bez próby spojrzenia wstecz $i$ odwołania się do przeszłości. Uwzględnienie przeszłości szkolnego ruchu krajoznawczo-turystycznego w Polsce w procesie dydaktyczno-wychowawczym prowadzonym w aspekcie krajoznawstwa $\mathrm{i}$ turystyki wynika $\mathrm{z}$ poczucia ciąglości tej pracy. Jest ono spoiwem dokonań kilku pokoleń, wyrazem szacunku i poszanowania dla wartości, które w sposób trwały i chlubny zapisały się w kronikach oświaty oraz historii krajoznawstwa i turystyki w Polsce.

Krajoznawstwo i turystyka w Polsce moga poszczycic się wybitnymi postaciami. Wytyczyły one drogi, formy i metody postẹpowania. Dążąc do upowszechnienia idei krajoznawstwa i turystyki, zwłaszcza wśród młodzieży, powinniśmy znać tradycje tego ruchu i szczególnie tych, którzy swą pracą wnieśli twórczy wkład w rozwój poznawania ojczystego kraju i przygotowali grunt dla pracy przyszłych pokolen. Historia krajoznawstwa i turystyki w Polsce jest niezwykle ciekawa i pouczająca. Stanowić może doskonały temat pracy szkolnych kół 
(klubów) krajoznawczo-turystycznych, szkolnych kól PTTK oraz innych zainteresowanych tą problematyką zespołów pozalekcyjnych i pozaszkolnych, a także przemyśleń opiekunów SKKT, działaczy ZHP, PTTK i PTSM.

\section{Kola Krajoznawcze Młodzieży Szkolnej PTK}

Działalność krajoznawczo-turystyczna wśród młodzieży i dla młodzieży byla jednym z głównych zadań Polskiego Towarzystwa Krajoznawczego. Propozycje zorganizowanego włączenia młodzieży do pracy krajoznawczej przedłożył profesor geografii Uniwersytetu Jagiellońskiego - Ludomir Sawicki - na zebraniu Oddziału Krakowskiego PTK 11 V 1919 r. Do kierowania działalnością krajoznawczą w środowisku młodzieży szkolnej powołano 16 VI 1919 r. Sekcję Kół Krajoznawczych Młodzieży Szkolnej PTK pod przewodnictwem profesora VII Gimnazjum Państwowego w Krakowie - Leopolda Węgrzynowicza. Współpracowali z nią m.in. profesorowie: Walery Goetel, January Kołodziejczyk, Stanisława Niemcówna, Kazimierz Nitsch, Władysław Semkowicz, Władysław Szafer, Seweryn Udziela. Powołanie Sekcji Kół Krajoznawczych Mlodzieży Szkolnej PTK uważa się za początek zorganizowanego ruchu krajoznawczo-turystycznego młodzieży szkolnej w Polsce.

Koła Krajoznawcze Młodzieży Szkolnej PTK zaczęły powstawać w całej Polsce. W celu koordynacji ich pracy Rada Główna PTK powołała w dniu 19 III 1927 r. Komisję Kól Krajoznawczych Młodzieży Szkolnej PTK z siedzibą w Krakowie. W jej skład weszli opiekunowie kół, przewodniczącym zaś został Leopold Węgrzynowicz. Komisja wydała broszurę pt. Kola Krajoznawcze Mlodzieży Szkolnej PTK (kolejne wydania ukazały się w 1. 1927, 1934, 1937, 1947) która była ważną pomocą w działalności szkolnego ruchu krajoznawczo-turystycznego.

O stałym rozwoju idei krajoznawstwa i turystyki wśród młodzieży świadczy rozwój organizacyjny Kół Krajoznawczych Młodzieży Szkolnej PTK. Liczba ich w I. 1919, 1927, 1932, 1935 kształtowała się odpowiednio: 7, 47, 328, 412. Przed wybuchem II wojny światowej dzialało ok. 500 kól. Zrzeszały one ponad 15.000 członków. Najsilniejszymi ośrodkami szkolnego ruchu krajoznawczo-turystycznego były: Kraków, Wilno, Warszawa, Lwów, Poznań, Lublin, Katowice, Tomaszów Mazowiecki, Bochnia, Krzemieniec, Tamów, Częstochowa, Kościerzyna, Czamków, Żywiec, Krotoszyn, Szamotuly, Wlocławek, Szopienice, Jasło. Wobec stałego rozwoju kół powołano komórki terenowe - nauczycielskie ogniska krajoznawcze. W 1932 r. działały one w Krakowie, Warszawie, Bydgoszczy, Poznaniu, Wilnie.

Koła Krajoznawcze Młodzieży Szkolnej PTK wydawały miesięcznik „Orli Lot” w nakładzie do 3000 egz. Pierwsze dwa numery tego pisma ukazały się pod tytułem „Miesięcznik Krajoznawczy dla Młodzieży - Organ Sekcji Kół Krajoznawczych Oddziału Krakowskiego PTK", nr 1 i 2, kwiecień-maj 1920. Lamy pisma wypetniały prace młodych krajoznawców i ich opiekunów. Oprócz „Orlego Lotu” - niektóre KKMS wydawały własne pisma o charakterze krajoznawczym. Należały do nich m.in.: „Nasza Radość” (Koło Szkoły Podstawowej nr 2 w Krakowie), „Nasze Echo” (Koło Szkoły Podstawowej nr 15 w Lublinie), „Nasz Widnokrąg” (Koło Liceum Krzemienieckiego). W Liceum Krzemienieckim poza miesięcznikiem „Nasz Widnokrąg”, ukazywało się „Życie Krzemienieckie” (dwutygodnik) i „Drogi Pracy” (miesięcznik). Wszystkie poświęcaly wiele uwagi różnym aspektom krajoznawstwa. Poza tym wychodziły: „Strażnica Kresowa” (Krotoszyn), „Nowiny Krajoznawcze” (Kraków), „Młody Krajoznawca Śląski” (Chorzów), „Ziemia Nadnotecka” (Czarnków), „Mlody Geograf” (Jasło), „Młody Krajoznawca” (Lublin), „Z Grodu Halszki” (Szamotuły).

Formy pracy KKMS były różnorodne. Największym uznaniem cieszyły się wycieczki, wieczornice, odczyty, obozy, wystawy krajoznawcze, gromadzenie materiału w oparciu o ankiety i kwestionariusze, opracowane przez placówki naukowe. Prace młodzieży zrzeszonej w KKMS w dziedzinie badań nad gwara, zabytkami i folklorem znalazły uznanie pracowników nauki. Wiele osób pod wpływem pracy krajoznawczej obrało droge pracy naukowo-dydaktycznej. 
Komisja ustaliła dla członków KKMS odrębną odznakę organizacyjna, zawierającą orle gniazdo na tarczy, wprowadziła jednolitą pieczątkę; organizowała zjazdy i zloty ogólnokrajowe oraz regionalne, na które młodzież przybywała w barwnych strojach regionalnych, budząc powszechne zainteresowanie. Zjazdy przedstawicieli KKMS i ich opiekunów połączone $z$ wystawami najcenniejszych prac, dyskusjami o działalności kół i komisji, wieczornicami wypełnionymi inscenizacjami z życia wybranych regionów zaczęto organizować od $1927 \mathrm{r}$. Odbywały się one kolejno w: Krakowie, Wilnie, Poznaniu, Krzemieńcu, Warszawie, Bydgoszczy, Pińsku i Lwowie. Odegrały poważną rolę w rozwoju KKMS. Pobudzały do pracy, umożliwiały wymianę doświadczeń, ułatwiały kontakty osobiste opiekunom kół i młodzieży, pozwalały precyzować nowe kierunki działalności. Były przedsięwzięciem pogłębiającym ideologię krajoznawczą i pobudzającym do ożywienia działalności Kół Krajoznawczych Młodzieży Szkolnej PTK.

II wojna światowa spowodowała duże straty w szeregach krajoznawców i turystów oraz w ich dokonaniach. W 1945 r. z trudem skupiła się ocalała garstka krajoznawców, by podjąc prace w restytuowanych organizacjach - Polskim Towarzystwie Tatrzańskim i Polskim Towarzystwie Krajoznawczym. Oba Towarzystwa rozpoczęły aktywną działalność. Włączyły się bezzwlocznie w nurt nowego życia. PTK rozpoczęło szeroko zakrojoną akcję wydawniczą, popularyzującą w szczególności piękno Ziem Zachodnich i Pólnocnych.

Po przebudowie organizacyjnej PTK reaktywowano także Kola Krajoznawcze Młodzieży Szkolnej. W 1946 r. ówczesny minister oświaty Czesław Wycech wydał okólnik zachęcający do organizowania w szkołach Kól Krajoznawczych Młodzieży Szkolnej PTK.

6-9 V 1948 r. odbył się w Warszawie pierwszy powojenny a dziesiąty z kolei Ogólnopolski Zjazd KKMS. Młodzież w uroczystym pochodzie złożyła wieniec na Grobie Nieznanego Żołnierza, odbyła wycieczki po dzwigającej się z ruin stolicy, przeprowadziła obrady w gmachu ZNP. Do uczestników Zjazdu przemówił prof. dr Stanisław Leszczyński, prezes ZG PTK. Odbyła się też wycieczka na Warmię i Mazury.

Pod koniec 1950 r. istniało w kraju 640 Kół Krajoznawczych Młodzieży Szkolnej PTK, skupiających ok. 25.000 członków. Dla Kół tych nie znalazło się miejsce w PTTK, powstałym z polączenia PTT i PTK. KKMS przy szkołach powszechnych podporządkowano harcerstwu, a koła istniejące w szkołach średnich - Związkowi Młodzieży Polskiej. Odbyło się to z dużą szkodą dla szkolnego ruchu krajoznawczo-turystycznego. Działalność KKMS w tym czasie znacznie osłabła, chociaż w większości nie przerwały one swych prac. Przestał się ukazywać „Orli Lot”.

\section{Szkolne Koła Krajoznawczo-Turystyczne}

Na początku 1951 r. opiekę nad Kołami Krajoznawczymi Młodzieży Szkolnej przejęło Ministerstwo Oświaty. Powołało ono pod koniec tego roku dwa Międzyszkolne Ośrodki Krajoznawczo-Turystyczne, w Gdańsku i Krakowie. Próba utworzenia przykładowych ośrodków dla szkolnego ruchu krajoznawczo-turystycznego w praktyce nie dała oczekiwanych wyników, niezbędna była bowiem systematyczna, fachowa opieka władz szkolnych i nauczycieli. Opiekę taka zapewnił dopiero powolany 1 XII 1956 r. - w ramach Departamentu Wychowania Fizycznego i Przysposobienia Wojskowego - Wydział Krajoznawstwa i Turystyki, na którego czele stanął zasłużony krajoznawca i turysta Józef Kuran. Przygotowano solidne podstawy prawne regulujące działalność krajoznawczo-turystyczną w szkole. Powołano Centralną Komisję ds. Krajoznawstwa i Turystyki Szkolnej. Podstawowym ogniwem pracy krajoznawczej w szkole stały się Szkolne Koła Krajoznawczo-Turystyczne. Przejęły one chlubne i zobowiązujące tradycje Kół Krajoznawczych Młodzieży Szkolnej PTK. SKKT zabrały się do pracy z dużą ambicją i rozmachem. W rozwoju i doskonaleniu działalności krajoznawczo-turystycznej w szkole znaczną pomoc okazał miesięcznik krajoznawczo-turystyczny „Poznaj Swój Kraj”. Pierwszy numer tego pisma ukazal się w styczniu 1958 r. Od tego czasu ukazują się w nim wartościowe artykuły slużące wzbogacaniu form i metod działalności krajoznawczo-turystycznej w szkole. Wychodzi on jako barwny 32-stronicowy magazyn, o nakładzie ok. 10.000 egz. Rzeczywista liczba czytelników jest co najmniej pięciokrotnie 
większa. „Poznaj Swój Kraj”, w przeciwieństwie do swego poprzednika - „Orlego Lotu”, który ograniczył tematykę wyłącznie do Kół Krajoznawczych Młodzieży Szkolnej PTK - z czasem stal się organem całego młodzieżowego ruchu krajoznawczo-turystycznego. Porusza tematykę wspólną dla wszystkich spraw związanych z działalnością krajoznawczo-turystyczną młodzieży szkolnej, harcerskiej, studenckiej, pracującej.

W 1957 r. po raz pierwszy objęto statystyka ruch wycieczkowy i młodzież bioracą w nim udział, SKKT, schroniska i ich wykorzystanie, stwarzając okazję do analizy i oceny rozwoju szkolnego ruchu krajoznawczo-turystycznego. Liczba SKKT w latach 1957, 1960, 1965, 1970, 1975, kształtowała się następująco: $2165,4946,6052,8323,8415$. Skupiały one: $70685,155431,162308$, 265490,305480 czlonków.

Powstałe we wszystkich województwach i większości powiatów szkolne (wojewódzkie, powiatowe) ośrodki krajoznawczo-turystyczne stały się komórkami koordynującymi całą działalność szkolnego ruchu krajoznawczo-turystycznego na swoim terenie. Organizowały liczne imprezy krajoznawczo-turystyczne, prowadzone samodzielnie lub z PTTK i PTSM oraz organizacjami młodzieżowymi.

Ważnym wydarzeniem $w$ rozwoju SKKT stal się II Ogólnopolski Zlot Krajoznawczy Młodzieży Szkolnej. Odbył się on 5-6 V 1962 r. w Warszawie. Ustalono na nim program szkolnego ruchu krajoznawczo-turystycznego, ujęty w następujące hasła: poznajemy kraj, jesteśmy użyteczni, zdobywamy wiedzę, służymy nauce i kulturze, jesteśmy przyjaciółmi przyrody, poznajemy życie innych narodów, dbamy o zdrowie, pomnażamy radość życia. Zasadniczymi elementami tego programu były: umasowienie zajęc krajoznawczo-turystycznych i powiązanie ich z całokształtem pracy dydaktyczno-wychowawczej szkoły, zwrócenie większej uwagi na sprawy dnia dzisiejszego i perspektywy rozwoju kraju, skoncentrowanie się na poznaniu najbliższego środowiska, podkreślenie społecznej użyteczności zajęć krajoznawczo-turystycznych. Program ten uwzględniał też konieczność ściślejszej współpracy z PTTK.

\section{Szkolne Kluby Krajoznawczo-Turystyczne PTTK}

Wraz z przeobrażeniami w organizacjach młodzieżowych i systemie oświatowym dokonały się zmiany organizacyjne w szkolnym ruchu krajoznawczo-turystycznym. Znalazło to odbicie w Zarządzeniu Ministra Oświaty i Wychowania z 4 VII 1977 r. w sprawie szkolnego ruchu krajoznawczo-turystycznego (Dz.Urz. MOiW 1977, nr 7 poz. 51). W myśl tego zarządzenia dzialające dotąd w szkołach i innych placówkach oświatowo-wychowawczych Szkolne Koła Krajoznawczo-Turystyczne i szkolne koła PTTK przekształcono w Szkolne Kluby Krajoznawczo-Turystyczne PTTK. Stwierdzono też, że w szkołach i innych placówkach oświatowo-wychowawczych program krajoznawczo-turystyczny realizowany będzie przez społeczny ruch uczniów, nauczycieli i rodziców w ramach działalności Związku Harcerstwa Polskiego i Szkolnych Klubów Krajoznawczo-Turystycznych Polskiego Towarzystwa Turystyczno-Krajoznawczego (SKKT PTTK). Koordynację tej działalności powierzono radom ZHP. Przeobrażeniom tym towarzyszyło zmniejszenie liczby SKKT PTTK i ich członków. W 1980 roku było 5539 SKKT PTTK, które zrzeszały 296793 członków.

Jako organ doradczy Ministra Oświaty i Wychowania w sprawach szkolnego ruchu krajoznawczo-turystycznego powołano Centralny Zespół Turystyki Szkolnej. Powierzono mu dokonywanie okresowych analiz i ocen działalności krajoznawczo-turystycznej wśród dzieci i młodzieży, opiniowanie materiałów i projektów dokumentów opracowanych przez Ministerstwo Oświaty i Wychowania, Główną Kwaterę ZHP, Zarząd Główny PTTK i Zarząd Główny PTSM, inicjowanie lub opiniowanie centralnych imprez turystycznych, konkursów, zawodów itp, określanie kierunków rozwoju bazy materialnej szkolnego ruchu krajoznawczo-turystycznego.

Większość nauczycieli kraju ojczystego potraktowało zarządzenie z dnia 4 lipca 1977 r. jako nacisk administracyjny, a w wielu przypadkach SKKT PTTK okazały się ogniwami fikcyjnymi, istniejącymi jedynie w dokumentacji administracyjnej. W okresie tym zmniejszyła się liczba Harcerskich Klubów Turystycznych. Nie znajdowały możliwości działania w szkołach Koła 
PTSM. Dlatego też Ministerstwo Oświaty i Wychowania opracowało program rozwoju krajoznawstwa i turystyki na lata 1979 - 1980, obejmujący zadania rozwoju organizacyjnego dotyczącego zwiększenia liczby różnorodnych form krajoznawstwa i turystyki na terenie szkoły oraz liczby ich uczestników, poprawę kadry i bazy materialnej szkolnego ruchu krajoznawczo-turystycznego. Program ten po dwuletniej realizacji przez jednostki terenowe i Ministerstwo Oświaty został podsumowany i zamknięty wnioskami na II Krajowej Naradzie Aktywu Krajoznawczo-Turystycznego. Okazało się, że wiele wątpliwości budzi zbytnio sformalizowany, mało przejrzysty i zagmatwany system organizacyjno-prawny krajoznawstwa i turystyki w szkole. Tworzono go niewątpliwie pod auspicjami rozsądku, a zapewne też w najlepszej wierze. Dopatrywano się w nim nawet przysłowiowych złotych gór dla pracy dydaktyczno-wychowawczej prowadzonej w formie zajęć krajoznawczo-turystycznych. Tymczasem w wyniku jego stosowania wyłoniły się zaledwie łagodne pagórki. Oznacza to, że efekty okazały się dalekie od zamierzeń władz szkolnych, ZHP, PTTK i PTSM, a jeszcze dalsze od oczekiwań dzialaczy szkolnego ruchu krajoznawczo-turystycznego. Stwierdzono, że praca większości SKKT PTTK jest płytka i bezbarwna.

Szkolne Kluby Krajoznawczo-Turystyczne (SKKT) stały się kontynuatorami działalności Kól Krajoznawczych Młodzieży Szkolnej PTK, Szkolnych Kół Krajoznawczo-Turystycznych. Dlatego wzbudza dyskusję nazwa Szkolny Klub Krajoznawczo-Turystyczny PTTK. Nie nawiązuje się w tej nazwie do tradycji szkolnego ruchu krajoznawczo-turystycznego w naszym kraju. Zawsze w nim podstawową komórką organizacyjną było koło. Wyraz „klub” niepotrzebnie akcentuje hedonistyczną funkcję tego ruchu. Tymczasem bardziej istotne dla niego są funkcje poznawczo-wychowawcze i zdrowotne. Nazwa „klub" wskazuje na zamknięty charakter krajoznawstwa i turystyki w szkole (only member). Jak wiadomo, chodzi zupełnie o coś odwrotnego - pozyskanie szerokiego kręgu dzieci i młodzieży do działalności krajoznawczo-turystycznej. Ponadto „klub” narusza jednolitą strukturę organizacyjną PTTK, w której zasadniczą jednostką organizacyjną są koła. $\mathbf{Z}$ tych względów podstawowa jednostka pracy krajoznawczo-turystycznej w szkole powinna otrzymać tradycyjną nazwę Szkolnego Koła Krajoznawczo-Turystycznego'.

\section{Powrót do nazwy Szkolne Kola Krajoznawczo-Turystyczne}

Działalności krajoznawczo-turystycznej w szkole nadano nowy, ściśle związany z procesem dydaktyczno-wychowawczym, sens, rangę w Zarządzeniu Ministra Oświaty i Wychowania z dnia 12 maja 1983 r. w sprawie szkolnego ruchu krajoznawczo-turystycznego (Dz. Urz. MOiW, 1983, nr 5, poz. 30). Zgodnie z nim szkolna działalność krajoznawczo-turystyczna powinna być realizowana przez Szkolne Koła Krajoznawczo-Turystyczne (SKKT), utworzone jako koła zainteresowań w ramach zajeć pozalekcyjnych w szkołach i innych placówkach oświatowo-wychowawczych. Równocześnie w Zarządzeniu stwierdza się, że „działalność krajoznawczo-turystyczną na terenie szkoły (placówki) może również organizować samorząd uczniowski, PTTK, ZHP, PTSM oraz inne organizacje dzialające na terenie szkoły (placówki) - w ramach wlasnych programów pracy i właściwych dla siebie struktur organizacyjnych".

W latach 1985-1990 nastąpiło dalsze zmniejszenie liczby SKKT i SKKT PTTK i ich członków. Na terenie szkół działało w tym czasie odpowiednio 6099 i 4896 SKKT i SKKT PTTK. Skupiały one 299289 i 195993 członków.

Wśród czynników determinujących efektywność szkolnego ruchu krajoznawczo-turystycznego szczególne miejsce zajmuje jego baza noclegowa. Stanowią ją szkolne schroniska młodzieżowe. Służą one upowszechnianiu krajoznawstwa i turystyki wśród młodzieży szkolnej, zapewniając jej tanie noclegi, opiekę wychowawczą i informację krajoznawczo-turystyczną. Szkolnymi schroniskami młodzieżowymi administrują i nadzorują władze oświatowe, a programowo organizuje je Polskie Towarzystwo Schronisk Młodzieżowych. Tworzy ono na terenie szkół swe koła.

' K. Denek, Tradycje i stan aktuainy krajoznawstwa i turystyki w szkole (cześc I). nSzkała Zawodowa" 1986, nr 11, s. 26-32; K. Denek, Tradycje ... (czest II). „Szkola Zawodawa" 1986, nr 12, a 37-41. 
Z organizacji społecznych, wspóldziałających ze szkolnym ruchem krajoznawczo-turystycznym, na.jwięksszymi osiągnięciami może poszczycić się Polskie Towarzystwo Turystyczno-Krajoznawcze. Do najciekawszych jego inicjatyw programowych, realizowanych w środowisku młodzieży szkolnej, należy zaliczyć ogólnopolskie młodzieżowe turnieje krajoznawczo-turystyczne. Bierze w nich udział młodzież szkỏł podstawowych i średnich. W czasie eliminacji sprawdza się wiadomości krajoznawcze, umiejętn ości praktyczne uprawiania turystyki, ocenia się kulturę biwakowania. Znacznym zainteresowaniem cieszą się popisy krasomówcze, organizowane w Golubiu-Dobrzyniu. W okresie wakacyjnym kontynuowane są akcje szkoleniowe młodzieżowych organizatorów turystyki na centralnych obozach szkoleniowych PTTK. Stworzono Młodzieżową Służbe Kultury Szlaku. Z okazji corocznych Dni Turystyki organizowane są sesje metodyczne, sejmiki i narady, również z udziałem młodzieży szkolnej. Powstała w 1984 r. Młodzieżowa Szkoła Turystyki spotkała się z dużym zainteresowaniem. Jej zadaniem jest zapoznanie młodzieży należącej do Szkolnych Kół (Klubów) Krajoznawczo-Turystycznych PTTK z krajoznawczym i turystycznym abecadłem. Podstawą tych lekcji są obozy organizowane i bezpośrednio realizowane przez poszczególne Oddziały PTTK. Zajęcia teoretyczne i praktyczne Mlodzieżowej Szkoły Turystyki obejmują takie zagadnienia, jak: krajoznawstwo wczoraj i dziś, zabytki i ich odnowa, las i ochrona przyrody, medycyna w plecaku, organizacja wycieczki, ekwipunek i sprzęt, kuchnia pod chmurką Młodzieżowe Szkoły Turystyki są realizowane w ramach obozów. Mają one różny charakter. W Gorcach, Pieninach, Tatrach, Beskidzie Sląskim i Żywieckim organizowane są turnusy pod hasłem „Młodzieżowa Szkoła Górska”, w Ciechanowcu - obozy opiekunów zabytków, w Brodnicy - obozy archeologiczne, a w Chodzieży - młodzieżowe szkoły imprez na orientację. Amatorzy fotografii spotykają się w Szczyrku, Kamieniu Pomorskim, na Górze Sw. Anny. Ciekawe w formie i treści s̨̨ także obozy krajoznawczo-turystyczne rozmieszczone na Roztoczu, w dolinie Pilicy, w Jurze Krakowsko-Częstochowskiej.

Oprócz tych obozów - które mają charakter ogólnopolski - na terenie poszczególnych województw organizowane są inne, równie atrakcyjne, przeznaczone dla młodych ludzi interesujących się krajoznawstwem i turystyką. Przykładowo dużą popularnością cieszą się obozy o problematyce ekoturystycznej organizowane przez M. Ratajskiego - prezesa Oddziału PTTK im. M. R. Witanowskiego w Piotrkowie Trybunalskim nad Zalewem Sulejowskim².

PTTK jest inicjatorem $\mathrm{i}$ organizatorem ciekawych konkursów. Przykładowo $-\mathrm{z}$ okazji 65-lecia uczestnictwa PTK i PTTK w szkolnym ruchu krajoznawczo-turystycznym - ZG PTTK wspólnie z Ministrem Oświaty i Wychowania, Związkiem Harcerstwa Polskiego, Polskim Towarzystwem Schronisk Młodzieżowych oraz redakcjami "Gościńca” i „Poznaj Swój Kraj” ogłosiły konkurs pod hasłem „Mój nauczyciel kraju ojczystego" 3 . Dzięki niemu organizatorzy zebrali - w formie wspomnień, opisów, relacji, pamiętników, dzienników, kronik - dokumentację o tych, którzy jako pierwsi wszczepiali dzieciom i młodzieży zamiłowanie do wędrówek, służących poznawaniu kraju ojczystego, jego przyrody, historii, zabytków, obyczajów, ludzi.

\section{Refleksje końcowe}

Co uderza w prezentacji tradycji LXXV-lecia zorganizowanego ruchu krajoznawczo-turystycznego w szkole i zestawieniu z jego aktualnym stanem? Przede wszystkim zwraca uwagę fakt, że aktualnie funkcjonujące $w$ nim formy organizacyjne są zbliżone. Obowiązujący program jest jakby tłumaczeniem na język współczesny zawsze żywch, aktualnych i potrzebnych idei krajoznawczo-turystycznych.

Wymienione w tytule tego artykułu sfery aktywności dały się poznać jako efektywne formy i metody działalności dydaktyczno-wychowawczej prowadzonej w aspekcie krajoznawstwa i turystyki wśród młodzieży. Krajoznawstwo uczy i wychowuje, kształtuje ludzi silnych, odważnych, szlachetnych, otwartych na służbę Ojczyźnie i Bogu.

\footnotetext{
'M. Ratajski, Ekoturystyka, „Poznaj Swój Kraj” 1994, nr 9.
}

${ }^{3}$ K. Denek, Nauczyciele kraju ojczystego. "Žycie Szkoły" 1981, nr 10, nr 11. 